\title{
Vulnerability and the governance of public space in the Post-COVID city
}

Vrushti Mawani (PhD Candidate, School of Community and Regional Planning, University of British Columbia, Vancouver)

\begin{abstract}
This essay outlines a research agenda on post-covid governance, and its impact on populations already vulnerable as a result of occupation, class, (im)migration status, religion, gender, race, and other factors. Drawing on recent instances of post-COVID governance in India, I reflect on its sudden, uneven, and heterogeneous impact on vulnerable populations that rely on urban public spaces for their basic needs. I question how these instances might influence meanings attached to public space and its use and governance. Reflecting on the scale and intensity of increased vulnerabilities experienced in public, I argue that these instances raise critical questions for urban scholars and new challenges for urban planners. Future work should include comparative research that examines the impact of public space governance on vulnerabilities and inequities across contexts. Such analysis may help inform future planning, public health policy, and public space governance in the post-COVID city.
\end{abstract}

Key words: COVID-19, public space, governance, vulnerability, planning

\section{Introduction}

On 25 March 2020, the Prime Minister of India announced a 3-week nationwide lockdown, effective four hours from the time of announcement, to curb the spread of COVID-19. Rapidly recognised for being the world's largest lockdown, this announcement meant that commercial activities were shut down, and transportation banned with essentially immediate effect. While the decision might have been necessary, its implementation at such short notice meant a sudden and unforeseen increase in 
vulnerability for specific groups, such as migrant workers (Adhikari et al, 2020), street vendors ${ }^{1}$, pavement dwellers ${ }^{2}$, residents of low-income informal settlements 3 , and others. Acquiring economic, physical, social, and psychological shape, these vulnerabilities have played out across multiple spatial arenas. However, these impacts have been most visible in public space, where the lockdown has been enforced through surveillance, patrolling, and in some instances, police violence.

\section{Vulnerability in the post-COVID city}

Public spaces are infused with, and emanate, "a sense of place", an amalgamation of socially and spatially specific aspects such as history, memory, meaning, and identity (Douglass and Daniere, 2009). In India for instance, public spaces such as streets, are "fluid, densely used, and intensely contested", and not merely occupied, but also "domesticated" (Anjaria, 2016 : 66). These descriptions draw on both, the affective - architectural, sensorial - qualities of these spaces, as well as the power structures, vulnerabilities, and inequalities they represent. They speak of the very busy economic life (sometimes referred to as the 'informal economy') that links back to global flows of goods, capital, information, and culture, and offers livelihood to millions that these streets support. And just as much, they allude to the reality that India's streets are home to many (see Appadurai, $2000: 636$ for instance).

As a result, the sudden and unplanned COVID-19 lockdown in India delivered an excruciating blow to those who rely on public spaces such as the city's streets for their basic needs - food, water, shelter. Street vendors became subject to violence and abuse by police and residents' associations alike for going about their usual work ${ }^{4}$. Pavement dwellers were unable to access food and water from their usual patrons (nearby residents, temples, passersby, etc) 5 . In many cases, they were also

\footnotetext{
1 https://thewire.in/labour/street-hawkers-lockdown

${ }^{2}$ https://indianexpress.com/article/cities/mumbai/for-pavement-dwellers-in-the-city-almost-no-accesscoronavirus-india-lockdown-to-water-6359658/

3 https://www.brookings.edu/blog/up-front/2020/04/16/are-slums-more-vulnerable-to-the-covid-19pandemic-evidence-from-mumbai/

${ }^{4}$ https://www.bbc.com/news/world-asia-india-52063286

5 https://indianexpress.com/article/cities/mumbai/for-pavement-dwellers-in-the-city-almost-no-accesscoronavirus-india-lockdown-to-water-6359658/
} 
not allowed to walk to hunger relief centres set up across cities ${ }^{6}$. Daily wage workers, migrants from other states, started walking back to their homes, tens and hundreds of kilometres away, with their families and belongings (Adhikari, et al., 2020). And if their pedestrian journeys back home were not arduous enough, many of these groups also encountered hunger, police violence, and lack of shelter along the way?

Some figures clarify the scale of the upheavals. Estimates suggest that India has over 20 million pavement dwellers ${ }^{8}$ (Das, 2016), over a 100 million rural-urban inter-state migrants (Deshingker and Akter, 2009), of which, a large share work in the informal sector (Khandelwal, et. al., 2012), and 10 million street vendors (Sankrit, 20159). Needless to say, there are likely overlaps between these groups. Indeed, much work is urgently needed to disaggregate these categories and examine the specific impacts of public space governance on each of these groups. Yet, these numbers offer a preliminary basis upon which to conceive the post-covid impacts enacted and experienced in public space.

\section{Emergent questions}

Given the nature of increased vulnerabilities and the numbers cited above, what does this augur for the ability of our cities' public spaces to attend to and accommodate difference and vulnerability? Across what variables of difference and vulnerability (class, religion, occupation, legality, geographical location, migration status, age, gender, etc) might the influence of post-covid governance be noted ? If public space is an amalgamation of history, memory, meaning, and identity, what new histories, memories, and meanings might these experiences enacted in public space constitute for already vulnerable groups ? Might we notice the emergence of new vulnerabilities as a result of hard mandates on social distancing and hygiene ? Further, what might these shifts mean for how public spaces such as India's streets are used, occupied, trusted, regulated, domesticated, and otherwise mediated in the future ? In turn, what considerations might

\footnotetext{
${ }^{6}$ https://news.trust.org/item/20200423122421-hibd0/

${ }^{7}$ https://scroll.in/article/960179/india-has-the-resources-to-care-for-its-embattled-migrant-workers-butdoes-it-have-the-will
}

${ }^{8}$ Some refer to this group of people as "homeless". I choose not to use this term since it brings into question the nature of "home", and the equation of home with shelter.

${ }^{9}$ http://www.inclusivecities.org/wp-content/uploads/2015/09/IC-Delhi-SV-Case-Study1.pdf 
urban planners need to be sensitive to and mindful of while conceiving inclusive public space in the post-covid city?

These questions first took shape through a collaborative paper that offers a broader contextualization of the impact of covid-19 on public space (Honey-Rosés et. al., 2020). Initial reports to date ${ }^{10}$, indicate that post-covid governance has had a sudden, uneven, and heterogeneous impact on multiple vulnerable population groups. The scale and intensity of increased vulnerabilities, often experienced in public space, raise critical questions for urban scholars and new challenges for urban designers and planners. They call for comparative research that examines the impact of public space governance on vulnerabilities and inequities across contexts. Such analysis may help inform future planning, public health policy, and public space governance in the post-COVID city.

\section{On governance and mediation}

A growing body of work has investigated and theorized how the interface between material infrastructures such as urban public space and everyday life is mediated (Weinstein, 2014 ; Weinstein et. al., 2019 ; Björkman, 2015 ; Anand, 2017). The need to study such mediating structures can be traced back to foundational arguments put forth, on the one hand by sociological inquiries into state-society relations (Abrams, 1988 ; Jessop, 1990 ; Hansen and Stepputat, 2001 ; Ferguson and Gupta, 2002 for instance), and on the other, by scholars of science and technology studies (Callon, 1998 ; Latour, 1993, 2005). Latour for instance, asserts that "any given interaction seems to overflow with elements which are already in the situation coming from some other time, some other place, and generated by some other agency" (2005 : 166). It is precisely these overflows from elsewhere that become mediating structures.

The "state-idea" then - erected and circulating in spatially and temporally specific contexts - needs to be understood as separate from the "state-system" - the actual institutional structures employed to govern (Abrams, 1988). However, the state system itself requires the acquiescence or complicity of non-state actors to propagate the state idea (Jessop, 1990), thus complicating the separation of the state idea from the state system ! For studies of public space, these two notions would suggest that, on the one hand, governance (however understood) needs to be separated from institutional

\footnotetext{
${ }^{10}$ I have been able to access these only remotely due to the ongoing lockdown in India
} 
structures meant to govern these spaces. On the other, the said institutional structures might themselves draw on myriad non-state actors for purposes of governing.

\section{Power, authority, and the disaggregated state}

It is in this context that Hansen and Stepputat (2001) argue for understanding everyday governance as "always suffused with and mediated by politics". They highlight the need for "disaggregated" studies of the state (9) that make visible the myriad forms of authority animating scales - neighbourhoods, communities, businesses - and illustrate how these influence governance. What then might such forms of authority enacted by a disaggregated state in the post-covid city look like?

Back in the city of Ahmedabad in India, starting 20 April 2020, the city's municipal corporation started referring to high-risk groups such as street vendors, grocery shop owners and attendants, garbage collectors, and others, as "super-spreaders" of the coronavirus owing to the mobility and high contact with others that is intrinsic to their occupations ${ }^{11}$. Surveillance ${ }^{12}$ and testing of these groups, in particular of fruit and vegetable vendors, was increased. These actions were publicised and lauded through television and print media, and circulated through social media. Starting 7 May 2020, an even stricter lockdown was announced, shutting down all supermarkets, grocery shops, and fruit and vegetable vendors - "super spreaders" - for one week, purportedly to test and issue clearance certificates to them ${ }^{13}$. As I write, these restrictions are still in place, expected to be lifted soon. But will the now popular imagination of these groups as being "super spreaders" of COVID-19 be dissipated just as quickly? How might this association mediate the use of public space by these groups? In extension, how might we better understand the role of the media in brokering postcovid governance and shaping post-covid public space?

There are varying estimates on the number of street vendors in Ahmedabad (see Mahadevia et. al., 2014 : 9 for instance), and none of these estimates are current. But in 2014, one NGO in the city, the Self Employed Women's Association (SEWA) had 75,000 women vendors registered only with them

11 https://www.indiatoday.in/india/story/ahmedabad-has-334-coronavirus-super-spreaders-sayauthorities-1676443-2020-05-10

12 Which in many cases amounted to verbal harassment and physical abuse by police

13 https://indianexpress.com/article/cities/ahmedabad/shutdown-curfew-coronavirus-lockdown-milkmedicines-covid-police-amc-commissioner-deaths-cases-6397291/ 
(ibid). Would post-covid governance mean specific vulnerabilities for women street vendors ? And in relation, how might organizations such as SEWA mediate post-covid governance?

Ferguson and Gupta (2002) locate disaggregated state authority in how governance unfolds (through images, metaphors, practices) as well as what organizational structures it unfolds through (media, NGOs, residents associations, etc). They also illustrate how such authority is spatialized. Everyday state authority, they assert, is exerted and experienced spatially through activities such as policing and surveillance across scales (the national border as much as the street), as well as by and through actors and organizations located at spatially varying hierarchical levels, from local areas, to villages, cities, regional centers, and so on (ibid). It is in this context that public authority, and by extension governance, is described as "the amalgamated result of the exercise of power by a variety of local institutions and the imposition of external institutions, conjugated with the idea of a state" (Lund, 2006 : 686). Further, the prescription of stability or even predictability to the exercise of power by a disaggregated state remains unsettled. Authority exercised by a certain set of institutions in one context might have a nearly hegemonic effect, while under a different set of conditions, authority exerted by a similar set of institutions might be fiercely challenged. A continuous change in composition of the amalgamation constituting the disaggregated state has thus been observed (ibid).

Anchoring the study of public space governance in the post-covid city within this literature allows us to ask numerous questions : through what relationships and practices is post-covid governance mediated ? How might the disaggregated state in relation to public space governance in the postcovid city be better understood? What kinds of authority do they exert ? To what end ? And what might these mean for urban vulnerability?

\section{In conclusion: are inclusive public spaces possible in the post- COVID city?}

The COVID public health crisis has raised a series of new challenges for planners and city managers (Honey-Rosés, et al, 2020). For urban researchers and scholars of public life in particular, it raises the question on whether inclusive spaces might be possible at all in a post-COVID city. Addressing this question, and those raised through this paper above, requires a critical and extensive engagement with what public space governance entails, how it is mediated, by whom, through what processes and practices, and to what end. As well, it calls for employing this understanding towards 
examining the impact of post-COVID governance on urban vulnerability. This essay is an attempt at outlining precisely such a research agenda.

On 31 March, a large Muslim gathering in Delhi became widely associated with the spread of COVID-19 throughout India ${ }^{1415}$. In Ahmedabad, this conflation further deepened with its already sharp Hindu-Mulsim divide (see Mawani, 2019 for more on the latter). Within a matter of hours, people started boycotting goods (such as bread and meat) which for centuries across urban India have been produced and supplied to a large extent by Muslims. How associations of this nature will shape the post-covid city, and what they will mean for our future physical, infrastructural, and economic environments remains to be seen. But in the immediate term at least, physical, social, economic, and environmental vulnerabilities are being experienced unevenly across class, religion, occupation and other variables. With many of these vulnerabilities resulting from the enactment of power and authority in public spaces, whether meanings associated with public spaces - and in extension, their "sense of place" - will change is a critical question.

The long term impact of increased vulnerabilities being experienced currently will depend to a large extent on how public space is governed and mediated in the post-covid city. The interests directing these mediations will shape the post-covid city.

\section{ACKNOWLEDGEMENTS}

I extend sincere thanks to my dissertation supervisor, Jordi Honey-Rosés, for inviting me to contribute to the collaborative paper "The Impact of COVID-19 on Public Space: A Review of the Emerging Questions" that facilitated the development of ideas offered through this paper, as well as for helping me sharpen this paper. I am also deeply grateful for Lisa Björkman's work, which has inspired much of my thought on infrastructure mediation.

\footnotetext{
${ }^{14}$ https://thewire.in/communalism/coronavirus-criminal-liability-of-tablighi-jamaat

${ }^{15}$ Not unlike United States President Donald Trump repeatedly referring to the coronavirus as "China Virus"
} 


\section{References}

1. Abrams, Philip, 1988 : Notes on the Difficulty of Studying the State : Journal of Historical Sociology ; 1(1) : 58 - 89

2. Adhikari, et al., 2020 : 21 Days and Counting : COVID-19 Lockdown, Migrant Workers, and the Inadequacy of Welfare Measures in India : Stranded Workers Action Network : accessible online at https://www.thehindu.com/news/resources/article31442220.ece/binary/Lockdown-andDistress Report-by-Stranded-Workers-Action-Network.pdf

3. Anand, Nikhil, 2017 : Hydraulic City: Water and the Infrastructures of Citizenship in Mumbai ; Duke University Press: Durham, NC, USA

4. Anjaria, Jonathan Shapiro, 2016 : The Slow Boil: Street Food, Rights, and Public Space in Mumbai ; Stanford University Press: Stanford, CA, USA

5. Appadurai, Arjun, 2000 : Spectral Housing and Urban Cleansing: Notes on Millenial Mumbai ; Public Culture, 12 (3) : 627-651

6. Bjorkman, Lisa, 2015 : Pipe Politics, Contested Waters: Embedded Infrastructures of Millennial Mumbai ; Duke University Press: Durham, NC, USA

7. Callon, Michel, 1998 : Introduction: The Embeddedness of Economic Markets in Economics ; $46(1): 1-57$

8. Das, Anupam, 2016 : Demography, Migration and Economic Condition of Pavement Dwellers - A Study of Most Marginalized Urban Poor in Central Business Areas of Kolkata, West Bengal ; International Journal of Science and Research, 5(6), 1496 - 1501

9. Deshingkar, Priya and Akter, Shaheen, 2009 : Migration and Human Development in India ; United Nations Development Programme Human Development Reports Research Paper

10. Douglass, Mike and Daniere, Amrita, 2009 : Urbanization and civic space in Asia ; in Daniere, Amrita, and Douglass, Mike ; The Politics of Civic Space in Asia : Building urban communities ; Routledge: New York, NY, USA : 1 - 18

11. Ferguson, James and Gupta, Akhil, 2002 : Spatializing States: Toward an Ethnography of Neoliberal Governmentality : American Ethnologist, 29 : 981-1002

12. Blom Hansen, Thomas and Verkaaik, O. Introduction-Urban Charisma: On Everyday Mythologies in the City. Crit. Anthropol. 2009, 29, 5-26

13. Honey-Roses, Jordi et. al., forthcoming : The Impact of COVID-19 on Public Space: A Review of the Emerging Questions ; preprint available at 
https://www.researchgate.net/publication/340819529 The Impact of COVID19 on Public Space A Review of the Emerging Questions

14. Jessop, Bob, 1990 : State Theory: Putting the Capitalist State in Its Place; Cambridge Polity Press: Cambridge, UK

15. Khandelwal et. al., 2012 : Creative Practices and Policies for Better Inclusion of Migrant Workers: The Experience of Aajeevika Bureau ; available online at http://www.aajeevika.org/assets/pdfs/Creative\%20Practices\%20and\%20Policies\%20Pap er Final.pdf

16. Latour, Bruno, 1993 : We Have Never Been Modern ; Harvard University Press : Cambridge, Massachusetts, USA

17. Latour, Bruno, 2005 : Reassembling the Social: An Introduction to Actor-Network- Theory; Oxford University Press: NY, USA

18. Lund, Christian, 2006 : Twilight institutions: Public authority and local politics in Africa. Dev. Chang. 2006, 37, 685-705

19. Mahadevia, Darshini, et. al., 2014 : Informal Economy Monitoring Study: Street Vendors in Ahmedabad, India : Manchester, UK: WIEGO.

20. Mawani, Vrushti, 2019 : Unmapped Water Access: Locating the Role of Religion in Access to Municipal Water Supply in Ahmedabad ; Water 2019, 11(6), 1282 ; available online at https://www.mdpi.com/2073-4441/11/6/1282

21. Sankrit, Ruchi, 2015 : SEWA Bharat and Street Vendors in Delhi : WIEGO ; available online at http://www.inclusivecities.org/wp-content/uploads/2015/09/IC-Delhi-SV-CaseStudy1.pdf

22. Weinstein, Liza, 2014 ; 'One-Man Handled': Fragmented Power and Political Entrepreneurship in Globalizing Mumbai : International Journal of Urban and Regional Research, 38(1) : 14-35 